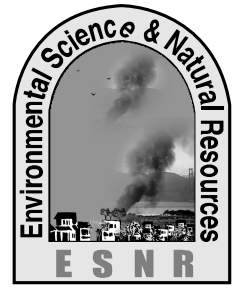

\title{
Growth Performance Meat Yield and Profitability of Broiler Chickens Fed Diets Incorporating Cassava Tuber Meal
}

\author{
F. Sultana ${ }^{1}$, M. A. Ali ${ }^{2}$ and I. Jahan ${ }^{1}$ \\ ${ }^{1}$ Department of Poultry Science, Bangladesh Agricultural University, Mymensingh \\ ${ }^{2}$ Department of Agricultural Chemistry, Bangladesh Agricultural University, Mymensingh
}

\begin{abstract}
A total of sixty, 14-day old broiler chickens (Cobb-500) of either sex were used in this study to assess the effects of processed cassava tuber meals $\left(0,15,30\right.$, and $\left.45 \mathrm{gkg}^{-1}\right)$ on growth responses, meat yield, and profitability of boilers; rearing from day 14 to day 33 of ages. The experimental diets were iso-caloric and iso-nitrogenous in nature, and were supplied the broilers ad libitum throughout the trial period. Broilers fed on control diet (i.e. exclusion of CTM) achieved higher $(\mathrm{P}<0.01)$ body weight, while the broilers offered diets with the highest amount $\left(45 \mathrm{gkg}^{-1}\right)$ of CTM had the lowest body weight. Increased (P<0.01) feed intake was observed in the treatments of $21 \mathrm{~d}$ and 28 days of age when broilers fed diets with the supplementation of CTM, but no significant differences was found among the dietary treatments in the feed consumption of the broilers during 33 day of age. FCR differed significantly $(\mathrm{P}<.01)$ throughout the trial period, broilers fed diets without supplementation of CTM had the superior FCR than the others. Mortality was unaffected by all the dietary treatment groups. Moreover, different body parts (feather, head, neck, wing, viscera) and meat yields (thigh, drumstick, breast, back, giblet, dressing) were not influenced by treatments. Live weights were unaffected by all the dietary groups with/without incorporation of cassava tuber meals (CTM) up to day 21 and day 28 of ages. Statistically significant $(\mathrm{P}<0.01)$ decreased live weight was observed among the treatments in 33 -day old birds.
\end{abstract}

Key words: Broiler, Cassava tuber meal, Growth performance, Meat yield

\section{Introduction}

Poultry industry is one of the most profitable ventures of agriculture in the today's world, owing to its potentialities of providing nutritious meat within shortest possible. Its meat is very nutritious, tasty, mild flavor, tender, easy to chew or grind, blended well with other foods, and easy to digest. According to the annual report of $\mathrm{WHO}, 55 \mathrm{~g}$ of animal protein is required for each person in a day, whereas only $15.6 \mathrm{~g}$ can consume (Huque, 2008). To reduce the gap between demand and supply of animal protein, poultry can play an important role. As a result, poultry industry has been expanding vastly in the last few decades to meet the challenge (Saleque, 2000).

Feed cost is comprised $65-75 \%$ of total production cost (Singh, 1990; Banerjee, 1992). Maize and wheat have traditionally been the ingredients of choice for the supply of carbohydrate, i.e. energy source for monogastric animal diets (PAN, 1995). The constant competition for wheat and maize among livestock, chickens, and human beings increases the cost of grains (USAID, 2005). The high cost of feed hardly permits remunerative and profitable poultry farming. The use of cereal products as livestock feed is increasingly unjustified in economic terms. Therefore, there is a need to exploit cheaper energy sources, to replace expensive cereals for poultry rearing (Raihan and Mahmud, 2008).

Nutritionists suggest that use of cheaper unconventional locally available dietary ingredients reduces the production cost (Rahman and Reza, 1983; Hossain et al. 1989). Substantial efforts have been made, in the past few decades, to replace cereals with other carbohydrate sources, such as sorghum (Rajasekher, 2000), lentils, cassava tuber meal (Garcia and Dale, 1999), leucaena root meal (Bhatnagar et al., 1996) in poultry feed. Among them cassava (Manihot esculenta) achieved a particular attention for its high production yield and high content of starch. It is an important food crops grown in the tropics (Hahn, 1989; Phillips et al. 2004), a significant source of energy for 500 million people mainly in Africa (FAO, 2000; Mroso, 2003) and very appropriate for purpose of poultry feed. It's tubers are very rich in starch $(69.89 \%)$ with an energy value of more than $3000 \mathrm{MJ}$ of metabolizable energy per $\mathrm{kg}$ (Kirchgessner, 1985), and also contains $1.70 \%$ of ash, $2.55 \%$ of $\mathrm{CP}, 27.75 \%$ of $\mathrm{CF}$, and $0.12 \%$ of $\mathrm{EE}$ on a DM basis (Sriroth et al. 2000). Under tropical conditions, cassava is the most productive crop in terms of stability of production and high yield (fresh tuber yield, 40-60 tones/ha) whereas maize and wheat yielded2 $0-25$ tons/ha and 
15-20 tonsha $^{-1}$, respectively (FAO, 1995). On contrary, due to the inclusion of cyanogenic glucosides in cassava root can easily convert to toxic $\mathrm{HCN}$ and depress the chick growth performance (Oke, 1978). However, it was reported that proper processing conditions can reduce $\mathrm{HCN}$ level in tolerance level (Padmaja, 1995). Thus, in the study we focused on the processing CTM properly, and incorporated to broiler diet and finally evaluated the effects of CTM on growth performance and meat yield of boiler.

\section{Materials and Methods}

Analysis of total HCN
Total HCN (ppm) in the CTM was analyzed using the enzymatic picrate paper kit developed by Bradbury et al. (1999). The absorbance was measured at $510 \mathrm{~nm}$ using a spectrophotometer, immersing the picrate papers to the sample in $5 \mathrm{~mL}$ distilled water for 30 minutes.

\section{Processing and formulation of diet}

Tubers were freed from dust, sliced and crushed, and socked in water, then dried in sunlight for 3 days. CTM was prepared by grinding cassava tuber slices in a Mortar and Pestle. All ingredients were weighed and then thoroughly mixed by hand according to the Table-1.

Table 1. Ingredients and chemical compositions of formulated dietary treatments.

\begin{tabular}{|c|c|c|c|c|}
\hline \multirow{2}{*}{ Ingredient $\left(\mathrm{gkg}^{-1}\right)$} & \multicolumn{4}{|c|}{ Treatment group } \\
\hline & $\mathbf{T}_{1}$ & $\mathbf{T}_{2}$ & $\mathbf{T}_{3}$ & $\mathbf{T}_{4}$ \\
\hline CTM & 0 & 15 & 30 & 45 \\
\hline Maize & 575 & 411.7 & 251.0 & 89.30 \\
\hline Cassava & 0 & 150 & 300 & 450.00 \\
\hline Soybean meal & 208.6 & 225.0 & 223.0 & 221.10 \\
\hline Protein concentrate & 90.8 & 94.6 & 111.7 & 128.80 \\
\hline Rice polish & 100 & 100 & 100 & 100 \\
\hline Oyestershell & 15.6 & 9.0 & 5.7 & 2.30 \\
\hline $\mathrm{NaCl}$ & 2.6 & 2.4 & 2.00 & 1.70 \\
\hline Adivit GS(SMF Pharmaceutical) & 3.0 & 3.00 & 3.00 & 3.00 \\
\hline Choline chloride & 0.7 & 0.60 & 0.70 & 0.70 \\
\hline DL-methionine & 0.7 & 0.7 & 0.30 & - \\
\hline Coccicure (Reneta) & 0.5 & 0.5 & 0.50 & 0.50 \\
\hline Navacox (Navana) & 0.5 & 0.5 & 0.50 & 0.50 \\
\hline Toxin binder & 2.00 & 2.00 & 2.00 & 2.00 \\
\hline Total & 1000 & 1000 & 1000 & 1000 \\
\hline \multicolumn{5}{|l|}{ Nutrient content } \\
\hline $\mathrm{ME}\left(\mathrm{kcalkg}^{-1}\right)$ & 3000 & 3000 & 3000 & 3000 \\
\hline $\mathrm{CP}$ & 21 & 21 & 21 & 21 \\
\hline $\mathrm{CF}$ & 4.22 & 3.87 & 3.47 & 3.08 \\
\hline $\mathrm{Ca}$ & 1.18 & 1.00 & 1.00 & 1.00 \\
\hline Av.P & 0.45 & 0.50 & 0.57 & 0.66 \\
\hline $\mathrm{Na}$ & 0.18 & 0.18 & 0.17 & 0.16 \\
\hline Lys & 1.14 & 1.16 & 1.19 & 1.22 \\
\hline Arg & 1.29 & 1.30 & 1.30 & 1.29 \\
\hline Meth & 0.50 & 0.48 & 0.46 & 0.43 \\
\hline Meth+Cyst & 0.80 & 0.77 & 0.73 & 0.68 \\
\hline
\end{tabular}

\section{Dietary treatment groups of boiler}

This experiment was carried out at the Poultry Farm of Bangladesh Agricultural University, Mymensingh2202, Bangladesh. A total of sixty, 14-day old commercial broilers (Cobb-500) having similar weights of $336.25 \pm 2.698 \mathrm{~kg} / \mathrm{b}$ were collected from "Narish Poultry Farm", Shreepur, Gazipur. $900 \mathrm{~cm}^{2}$ of floor space was provided for each broiler. Continuous photo period of 23:30 hours was provided including the natural light and electrical bulb; and a dark period of 00:30 hour every day. Broilers were randomly distributed into four dietary treatment groups $\left(\mathrm{T}_{1}, \mathrm{~T}_{2}\right.$, $\mathrm{T}_{3}$, and $\mathrm{T}_{4}$ ) with three replications. The experimental diets were iso-caloric and iso-nitrogenous in nature, and were supplied the broilers ad libitum for 20 days of trial period. 


\section{Processing and evaluation of broiler meat}

Broilers were fasted from feed and water for twelve hours prior to kill. After completion of bleeding, the slaughtered broilers were immersed in hot-water at $51-55^{\circ} \mathrm{C}$ for 120 seconds in order to facile removal of feathers. Head, shanks, viscera, oil gland, kidneys, and lungs of the carcass were separated. Heart and liver were also removed from the remaining viscera; and quickly the gall bladder was cut off from the liver; and the pericardial sac and arteries were excised from the heart. The gizzard was removed by cutting from proventriculus and then cutting both incoming and outgoing tracts. Then, split was opened with knife, emptied and washed and the lining was removed by hand. Blood weight was calculated by deducting the slaughtered weight from the live weight of broilers after complete bleeding. Feather weight was calculated by deducting the complete defeathering broiler weight from the slaughtered weight of broilers. The weight of head, neck, viscera, heart, liver, gizzard, thigh meat, drumstick meat, back meat, and breast meat were determined individually by using the sensitive weighing balance. Dressing yield was calculated by subtracting the weight of blood, feathers, viscera and shank from the live weight. Giblet weight was the total weight of liver, heart, gizzard, lung and spleen. Dressed weights of broilers were calculated deducting the weights of head, neck and giblet from carcass

\section{Statistical analysis of the data}

All recorded and calculated data were statistically analyzed by MSTAT statistical computer package program in accordance with the principles of Completely Randomized Design. Least Significant (LS) differences were calculated to compare variations among diets where ANOVA showed significant differences.

\section{Results and Discussion}

\section{Effects of drying and soaking time on total HCN content of CTM}

Cassava tubers were harvested twelve months after planting. The tubers were peeled, immediately washed with tap water and sliced.

\section{Soaking time}

Fig. 1 showed the effect of soaking time on total HCN content of CTM. Highest amount of HCN (58 ppm) was found in the fresh tubers. It was observed that HCN content decreased sharply with soaking time. It reduced to 45, 28, and $15 \mathrm{ppm}$ after 5, 10 and 20 hours soaking respectively. Further increasing the soaking time, the level of $\mathrm{HCN}$ content decreased very slowly and leveled up at $12 \mathrm{ppm}$.

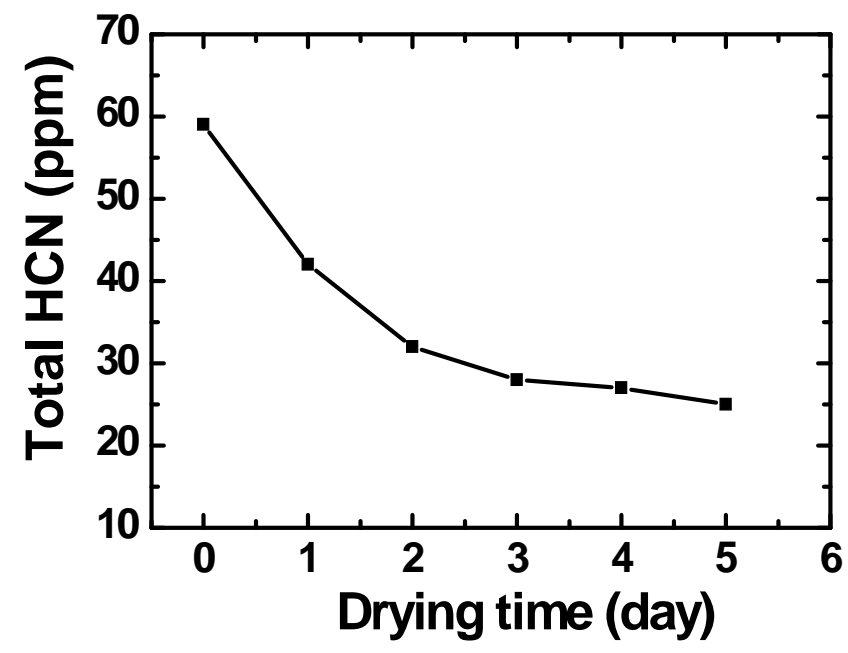

Fig. 1. Total HCN content as a function of drying time. 


\section{Drying time}

The different drying periods in sunlight resulted in a significant differences in the total $\mathrm{HCN}$ content, shown in Fig. 1. Initially, as increased the drying time the HCN content was decreased sharply. 1 day and 2 days dried CTM contained 42 and 32 ppm CTM respectively. After that, $\mathrm{HCN}$ content reduced slowly on 3,4 , and 5 days drying.

\section{a) Effects of CTM on growth performance of broiler}

The cassava root slices were soaked in water for 20 hours and dried in sunlight for 3 days subsequently. As a result, the level of $\mathrm{HCN}$ was reduced as low as $10 \mathrm{ppm}$. The processed CTM was incorporated at a level of $0,15,30$, and $45 \mathrm{~g} / \mathrm{kg}$ by substituting the costly maize; and other ingredients were added in a proportion to balance iso-caloric and iso-nitrogenous diets, shown in table-1.

\section{Live weight}

Fig. 3 showed the live weight of broilers of different treatment groups. It was observed that highest live was found in control group $\left(\mathrm{T}_{1}\right)$ and decreased slightly with CTM level. However, it was statistically insignificant up to $28 \mathrm{~d}$ of ages (Table 2, Fig. 2), then differed significantly $(\mathrm{P}<0.01)$ among different dietary treatment groups during 33 days of age. Live weights were $1235.29^{\mathrm{a}}, 1174.40^{\mathrm{b}}, 1125.6^{\mathrm{c}}$, and $1081.14^{\mathrm{d}} \mathrm{g}$ for the dietary treatment groups of $\mathrm{T}_{1}, \mathrm{~T}_{2}$, $\mathrm{T}_{3}$, and $\mathrm{T}_{4}$ respectively at $33 \mathrm{~d}$ of ages. Linear fashion decreased with CTM dietary may be due to the high level of fiber content in CTM, which reduced the digestibility of protein and subsequently affected the growth of broilers (Akintala et al., 2002).

Table 2. Effects of dietary treatments on live weight, feed intake, feed conversion ratio, and mortality.

\begin{tabular}{|c|c|c|c|c|c|c|}
\hline & \multirow{2}{*}{$\begin{array}{l}\text { Age } \\
\text { (day) }\end{array}$} & \multicolumn{4}{|c|}{ Treatment group } & \multirow{2}{*}{$\begin{array}{c}\text { SED and } \\
\text { significance }^{+}\end{array}$} \\
\hline & & $\mathbf{T}_{1}$ & $\mathbf{T}_{2}$ & $\mathbf{T}_{3}$ & $\mathbf{T}_{4}$ & \\
\hline \multirow{4}{*}{ Live weight $(\mathrm{g} / \mathrm{b})$} & 21 & 632.15 & 626.84 & 615.41 & 594.73 & $14.666^{\mathrm{NS}}$ \\
\hline & 28 & 960.58 & 958.33 & 937.45 & 907.09 & $23.620^{\mathrm{NS}}$ \\
\hline & 33 & $1235.29^{\mathrm{a}}$ & $1174.40^{\mathrm{b}}$ & $1125.6^{\mathrm{c}}$ & $1081.14^{\mathrm{d}}$ & $30.267^{* *}$ \\
\hline & 21 & $558.55^{\mathrm{d}}$ & $580.68^{\mathrm{c}}$ & $604.74^{\mathrm{b}}$ & $609.35^{\mathrm{a}}$ & $11.193^{* *}$ \\
\hline \multirow{3}{*}{ Feed intake $(\mathrm{g} / \mathrm{b})$} & 28 & $750.33^{\mathrm{c}}$ & $856.82^{\mathrm{b}}$ & $879.78^{\mathrm{a}}$ & $880.72^{\mathrm{a}}$ & $25.569^{* *}$ \\
\hline & 33 & 523.23 & 518.72 & 503.76 & 481.76 & $26.459^{\mathrm{NS}}$ \\
\hline & 21 & $1.90^{\mathrm{d}}$ & $2.00^{\mathrm{c}}$ & $2.16^{\mathrm{b}}$ & $2.36^{\mathrm{a}}$ & $0.077^{* *}$ \\
\hline \multirow{3}{*}{ Feed conversion ratio $(\mathrm{FCR})$} & 28 & $2.28^{\mathrm{d}}$ & $2.59^{\mathrm{c}}$ & $2.73^{\mathrm{b}}$ & $2.82^{\mathrm{a}}$ & $0.036^{* *}$ \\
\hline & 33 & $1.91^{\mathrm{d}}$ & $2.40^{\mathrm{c}}$ & $2.68^{\mathrm{b}}$ & $2.77^{\mathrm{a}}$ & $0.077^{* *}$ \\
\hline & 21 & 0.00 & 6.67 & 0.00 & 0.00 & $4.707^{\mathrm{NS}}$ \\
\hline \multirow{2}{*}{ Mortality rate } & 28 & 0.00 & 6.67 & 0.00 & 0.00 & $4.707^{\mathrm{NS}}$ \\
\hline & 33 & 6.67 & 6.67 & 0.00 & 0.00 & $6.657^{\mathrm{NS}}$ \\
\hline
\end{tabular}

Data represent mean values of three replicate groups consisting of 15 broilers each replicate during d 14 to 33 days. a,b,c,d Means bearing uncommon superscripts in a row are significantly different at $* * \mathrm{P}<0.01$; NS: Non significant, P>0.05; and Standard Error of the Difference (SED)'s are against 10 error degrees of freedom.

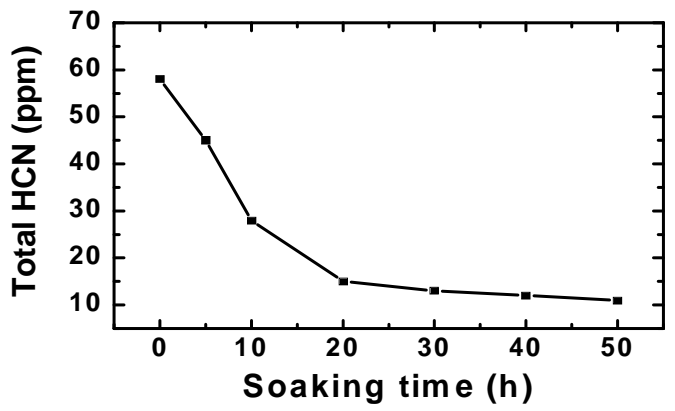

Fig. 2. Total HCN content as a function of soaking time

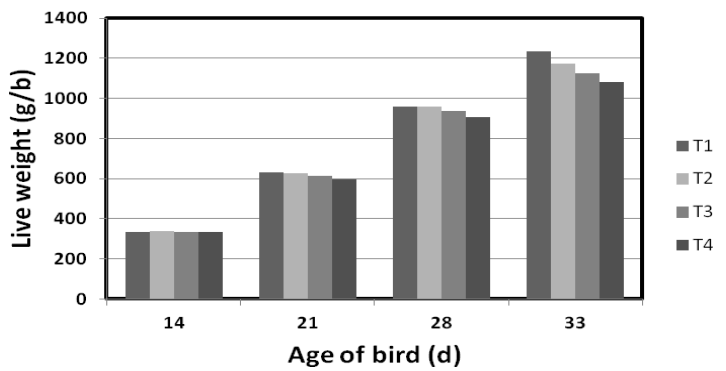

Fig. 3. Live weight of boiler as a function of age. Legend indicates the treatment groups 


\section{Feed intake}

It was observed that feed intake was slightly increased with dietary CTM (Table 2). The highest feed intake was found in $\mathrm{T}_{4}$ treatment group, whereas the lowest feed intake was found in $T_{1}$ control group regardless the age of birds. Furthermore, feed intakes of 21-day age broilers were $558.55^{\mathrm{d}}, 580.68^{\mathrm{c}}, 604.74^{\mathrm{b}}$, and $609.35^{\mathrm{a}} \mathrm{g}$ for $\mathrm{T}_{1}, \mathrm{~T}_{2}, \mathrm{~T}_{3}$, and $\mathrm{T}_{4}$ treatment groups respectively (Table-2). It was $750.33^{\mathrm{c}}, 856.82^{\mathrm{b}}$, $879.78^{\mathrm{a}}$, and $880.72^{\mathrm{a}} \mathrm{g}$ for 28 -day of age; followed by a declined at 33-day of ages. It might be due to the palatability/other factors. (Tewe, 1993; Onyimoyi and Ugwu, 2007; Onjoro et al., 2001; Maust et al., 2000).

\section{Feed Conversion Ratio (FCR)}

Feed conversion ratio (FCR) demonstrated the clear differences among the dietary treatments of CTM with ages of broiler, shown in Table-2. For all ages, the FCR were getting higher with the inclusion of CTM diets. The highest FCR was obtained in the $\mathrm{T}_{4}$ group and the lowest in $T_{1}$ group regardless of ages.
During 33-day of ages it was $1.91^{\mathrm{a}}, 2.40^{\mathrm{c}}, 2.68^{\mathrm{b}}$, and $2.77^{\mathrm{a}}$ for $\mathrm{T}_{1}, \mathrm{~T}_{2}, \mathrm{~T}_{3}$, and $\mathrm{T}_{4}$ treatment groups respectively. It indicated that CTM suppressed the growth of boiler regardless of age (Table-2).

\section{Mortality (\%)}

In this present study, percentage of mortality was insignificant among the dietary treatment groups (Table-2), suggested that CTM did not cause any fatal to boilers (Akintala et al. ,2002).

\section{b) Effects of CTM dietary on meat yield of boiler}

\section{Meat yield characteristics}

The meat yield characteristics of broiler regardless of dietary treatments were preserved the similar characteristics and insignificant in terms of statistical analysis $(\mathrm{P}>0.05)$, shown in Table-3, indicating that dietary supplementation of CTM and feeding time did affect notably on the characteristic of meat (Awojobi and Adekunmi, 2002).

Table 3. Meat yield characteristic of 33-day old broilers.

\begin{tabular}{|c|c|c|c|c|c|}
\hline & \multicolumn{4}{|c|}{ Treatment group } & \multirow{2}{*}{$\begin{array}{c}\text { SED and } \\
\text { significance }^{+}\end{array}$} \\
\hline & $\mathbf{T}_{1}$ & $\mathbf{T}_{2}$ & $\mathbf{T}_{3}$ & $\mathbf{T}_{4}$ & \\
\hline Live weight (g/b) & $1234.00^{\mathrm{a}}$ & $1174.00^{\mathrm{b}}$ & $1125.00^{\mathrm{c}}$ & $1080.00^{\mathrm{d}}$ & $* *$ \\
\hline Blood & 3.69 & 4.15 & 4.49 & 4.42 & NS \\
\hline Feather & 7.46 & 7.19 & 7.80 & 7.83 & NS \\
\hline Head & 2.64 & 3.09 & 2.91 & 2.67 & NS \\
\hline Neck & 2.45 & 2.01 & 2.06 & 2.00 & NS \\
\hline Giblet & 6.14 & 6.06 & 6.00 & 6.24 & NS \\
\hline Thigh & 9.20 & 9.26 & 9.92 & 9.74 & NS \\
\hline Drumstick & 8.40 & 8.27 & 8.93 & 8.85 & NS \\
\hline Wing & 8.02 & 8.30 & 8.38 & 8.83 & NS \\
\hline Breast & 10.73 & 10.82 & 10.42 & 10.27 & NS \\
\hline Viscera & 8.61 & 8.78 & 9.29 & 9.09 & NS \\
\hline Back & 9.60 & 9.86 & 9.74 & 9.82 & NS \\
\hline Dressing yield & 51.03 & 51.61 & 52.35 & 52.19 & NS \\
\hline
\end{tabular}

Data represent mean values of three replicate groups consisting of 15 broilers each replicate during d 14 to 33 days.

a,b,c,d Means bearing uncommon superscripts in a row are significantly different at $* * \mathrm{P}<0.01$; NS: Non significant, P>0.05; and Standard Error of the Difference (SED)'s are against 10 error degrees of freedom.

\section{c) Effects of CTM dietary on profitability of boiler}

\section{Production cost and profitability}

Feed cost was evaluated based on the current market price of the ingredients, considering $26 \mathrm{Tk}$ for maize and $12 \mathrm{Tk}$ for CTM. Productivity of cassava is almost three times higher than maize and wheat. It is expected that the inclusion of cassava meal in poultry ration will decrease the cost of the poultry rearing. Cassava meal will become cheaper when it will be cultivated commercially. On the contrary, for low content of protein in CTM, additional concentrated protein should be incorporated to ensure adequate protein, thus increased the cost of the ration some extent. Table- 4 shows the feed per boiler rearing up to 33-day of age. Feed cost reduced linear fashion from $60.02 \mathrm{Tk} / \mathrm{kg}$ for control diet to $53.83 \mathrm{Tk} / \mathrm{kg}$ for 45 $\mathrm{g} / \mathrm{kg}$ of CTM supplement. It was expected that inclusion of CTM, the price of the feed will be decreased by half. However, due to the incorporation 
of additional concentrated protein, it was not lowered much as anticipated. Moreover, because of higher amount of feed intake with CTM levels, reduced the net profit of per $\mathrm{kg}$ meat of boile, they were: 9.01 , 3.67, 1.74, and $1.51(\mathrm{Tk} / \mathrm{kg})$ for $\mathrm{T}_{1}, \mathrm{~T}_{2}, \mathrm{~T}_{3}$, and $\mathrm{T}_{4}$ respectively (Maust et al., 2000).

Table 4. Production and profitability of boiler rearing (33 days).

\begin{tabular}{|c|c|c|c|c|c|}
\hline & \multicolumn{4}{|c|}{ Treatment group } & \multirow{2}{*}{$\begin{array}{c}\text { SED and } \\
\text { significance }\end{array}$} \\
\hline & $\mathbf{T}_{1}$ & $\mathbf{T}_{2}$ & $\mathbf{T}_{3}$ & $\mathbf{T}_{4}$ & \\
\hline Feed cost $(\mathrm{Tk} / \mathrm{b})$ & $60.02^{\mathrm{a}}$ & $60.84^{\mathrm{a}}$ & $58.17^{\mathrm{b}}$ & $53.83^{\mathrm{c}}$ & $0.797^{* *}$ \\
\hline Feed cost $(\mathrm{Tk} / \mathrm{kg})$ & $48.59^{c}$ & $51.81^{\mathrm{a}}$ & $51.68^{\mathrm{a}}$ & $49.79^{\mathrm{b}}$ & $1.070^{* *}$ \\
\hline Total cost $(\mathrm{Tk} / \mathrm{b})$ & $118.58^{\mathrm{a}}$ & $119^{\mathrm{a}}$ & $116.23^{\mathrm{b}}$ & $111.89^{c}$ & $1.320^{* *}$ \\
\hline Total cost $(\mathrm{Tk} / \mathrm{kg})$ & $95.99^{c}$ & $101.33^{b}$ & $103.26^{\mathrm{a}}$ & $103.49^{\mathrm{a}}$ & $1.111^{* *}$ \\
\hline Meat price $(\mathrm{kg} / \mathrm{b})$ & 105 & 105 & 105 & 105 & $0.000^{\mathrm{NS}}$ \\
\hline Sale $(\mathrm{Tk} / \mathrm{b})$ & $129.71^{\mathrm{a}}$ & $123.31^{\mathrm{b}}$ & $118.19^{c}$ & $113.52^{\mathrm{d}}$ & $0.900^{* *}$ \\
\hline Profit (Tk/b) & $11.13^{\mathrm{a}}$ & $4.31^{\mathrm{b}}$ & $1.96^{\mathrm{C}}$ & $1.63^{\mathrm{c}}$ & $0.190^{* *}$ \\
\hline Profit (Tk/b) & $9.01^{\mathrm{a}}$ & $3.67^{\mathrm{b}}$ & $1.74^{\mathrm{c}}$ & $1.51^{\mathrm{c}}$ & $0.190^{* *}$ \\
\hline
\end{tabular}

Total cost includes feed cost, vaccine cost, and rearing cost. Taka (Tk) is the local currency; 1 dollar $=70$ Tk (approximately).

\section{Conclusions}

Unconventional feed ingredient cassava tuber meal was evaluated as an alternative carbohydrate supplement in boiler rearing by substituting the costly maize. With the introduction of CTM, feed cost decreased linearly. No significant mortality was recorded throughout the experimental trial period. The meat yield characteristics of broiler regardless of dietary treatments were preserved the similar characteristics. However, the high content of fiber and low content of protein inhibited the growth performance, thus decreased the profitability of boiler rearing.

\section{Acknowledgments}

Thanks to Professor Md. Solaiman Ali Fakir, Ph.D. for his constant help to accomplish this work and cassava tuber meal was collected from his experimental field, Department of Crop Botany, Faculty of Agriculture, Bangladesh Agricultural University, Mymensingh-2202, Bangladesh.

\section{References}

Akintala, E. O.; Aderibigbe, A. O. and Matanmi, O. 2002. Evaluation of the nutritive value of cassava tuber meal as replacement for maize in the starter diets for broiler chicken. Cali, Colombia: CIPAV Foundation, 14: 1-6.

Awojobi, H. A. and Adekunmi A. A. 2002. Performance of broilers fed graded levels of cassava tuber meal. New Delhi, India: Indian Council of Agricultural Research, 72: 1169-1172.
Banerjee, G. C. 1992. Poultry ( $3^{\text {rd }}$ edition). Oxford and IBH Publishing CO. Pvt. Ltd New Delhi, Bombay, Calcatta.

Bhatnagar, R; Kataria, M. and Verna, S. V. S. 1996. Effect of dietary Leucaena root meal on the performance and egg characteristics in white leghorn hens. Indian Journal of Animal Science. 66(12): 1291-1294.

FAO, 1995. Food and Agriculture Organization. Production Yearbook. Vol.49. FAO. Rome, Italy.

Hahn, S. K. 1989. An overview of African traditional cassava processing and utilization. Outlook on Agriculture. 18: 110-118.

Hossain, M. D.; Bulbul, S. M. and Howlider, M. A. R. 1989. The composition of some unconventional feeds. Poultry adviser. 22: 37-40.

Huque, Q. M. E. 2008. Poultry industry in Bangladesh and strategies for its improvement. Second International Poultry Show and Seminar, 2008. Word's Poultry Science Association of Bangladesh Branch.

Kirchgessner, M. 1985. Nutritive value of cassava plants for chicks. Poultry Science. 555: 19171921.

Maust, L. E.; W. G. Pond and Choun M. L. 2000. Energy value of cassava maize based diet with and without supplemental zinc for growing poultry. Journal of Animal Science. 35: 935-957.

Mroso, P. V. 2003. Cassava: An emerging food product, the consequence of its popularity. Http://www.suite1101.com/article.Cfm/16738/99 9964.

Oke, O. L. 1978. Problems in the use of cassava as animal feed. Feed Science Tech. 3(4): 345-380. 
Onjoro, P. A.; Bhattacharjee, M. and Ottaro, J. M. 2001. Bioconversion of cassava tuber by fermentation into broiler feed of enriched nutritional quality. Trivandrum, India: Indian Society for Root Crops, Central Tuber Crops Research Institute, 24: 105-110.

Onyimoyi, A. E. and Ugwu, S. O. C. 2007. Bioeconomic indices of broiler chicks fed varying ratios of cassava peel/bovine blood. Faisalabad, Pakistan: ANSI, Asian Network for Scientific Information, 6: 318-321.

Padmaja, G. 1995. Cyanide detoxification in cassava for food and feed uses. CRC Critical Reviews. Food Science \& Nutrition. 35(4): 299339.

PAN. Annual Reports. 1995. Poultry Association of Nigeria. Lagos. Nigeria. 33: 34-37.

Phillips, T. P.; Taylor, D. S.; Sanni, L. and Akoroda, M. O. 2004. A cassava industrial revolution in Nigeria: The potential for a new industrial crop. International Institute of Tropical Agriculture, Ibadan, Nigeria, International Fund for Agricultural Development, Food and Agriculture Organization of the United Nations, Rome, Italy, $43 \mathrm{pp}$.

Rahman, A. and Reza, M. A. 1983. Study on the effect of unconventional sources of protein and energy for poultry. M. Sc. Thesis. Department of Animal
Nutrition, Bangladesh Agricultural University, Mymensingh.

Raihan, S.; Mahmud, N. T. and Linkages, P. A. 2008. Case study of the poultry industry in Bangladesh. Cuts International. 1-15.

Rajasekher, R. A.; Ravinder, R. V.; Parthasarathy, R. P.; Gurava, R. K.; Belum, V. S. and Saleque, A. 2000. Scaling-up: The BRAC Poultry model in Bangladesh. Final Report.

Singh, R. A. 1990. Poultry Production ( $3^{\text {rd }}$ edition), Kalyany Publishers, New Delhi, Ludhiana.

Sriroth, K. R.; Chollakup, S.; Chotineeranat, K.; Piyachomkwan and Oates, C. G. 2000. Processing of cassava waste for improve biomass utilization. Bioresources Technology. 71: 63-69.

Tewe, O. 1993. Thyroid cassava toxicity in animals. Pages 114-118 in Cassava toxicity end thyroid: research and public health issues, Proceedings, International Workshop on Cassava Toxicity, edited by F. Delange and R. Ahluwalia, 31 May2 June 1993, Ottawa, Canada. IDRC-207e: Ottawa.

USAID. 2005. Issues and interventions in poultry. Final Report.

Haque, M. R. and Bradbury, J. H. 1999. Simple method for determination of thiocyanate in urine. Clinical Chemistry, 45:1459-1464. 